Jurnal PRIMATIKA, Volume 8, Nomor 2, Desember 2019

\title{
PEMAHAMAN SISWA BERKEMAMPUAN MATEMATIKA TINGGI DALAM PEMECAHAN MASALAH DIMENSI TIGA
}

\author{
Kurniawan \\ Dosen Pendidikan Matematika FKIP Universitas Mulawarman \\ Email: kurniawan@fkip.unmul.ac.id
}

\begin{abstract}
ABSTRAK
Penelitian ini bertujuan untuk mendeskripsikan pemahaman siswa berkemampuan matematika tinggi dalam pemecahan masalah dimensi tiga (geometri). Hasil penelitian yang diperoleh, pada fase memahami masalah subjek memiliki jaringan representasi tentang luas permukaan kubus, letak titik pada rusuk yang dinyatakan dalam bentuk perbandingan, titik potong diagonal sisi alas, sinus suatu sudut, sudut antara garis dan bidang dan prosedur memecahkan masalah. Terdapat juga jaringan representasi tentang rumus luas permukaan kubus, perbandingan, diagonal sisi, dan rumus sinus, cosinus, dan tangen. Kemudian jaringan representasi tentang prosedur yang akan dilakukan untuk memecahkan masalah. Selanjutnya dalam fase melaksanakan, subjek memiliki jaringan representasi tentang kubus, luas permukaan, letak titik pada rusuk yang dinyatakan dalam bentuk perbandingan, letak sudut antara garis dan bidang, sinus suatu sudut, diagonal sisi alas, dan pecahan yang penyebutnya dalam bentuk akar. Pada fase memeriksa kembali, subjek memiliki jaringan representasi tentang nilai sinus suatu sudut, dan jaringan representasi tentang letak sudut antara garis dan bidang serta hasil perhitungan pada setiap langkah.
\end{abstract}

Kata kunci: Pemahaman, Pemecahan Masalah, Kemampuan Matematika.

\begin{abstract}
This study aimed to describe the students' understanding of high mathematics ability in problem solving three-dimensional (geometry). The results obtained, the phase of understanding the subject matter has a network representation of the surface area of the cube, the location of the point on the ribs which is expressed in the form of comparison, the point of intersection diagonal side of the pedestal, sinus an angle, the angle between the line and the field and the procedures to solve the problemThere is also a network representation of the surface area of the cube formula, comparison, diagonal side, and the formula sine, cosine, and tangent. Then the network representation of the procedure to be done to solve the problem. Furthermore, in the phase of implementation, the subject has a network representation of a cube, surface area, location of points on the ribs which is expressed in the form of comparison, the location of the angle between the line and the field, sinus an angle, the diagonal side of the pedestal, and fractions with denominators in the form of roots. In the phase of checking back, the subject has a network representation of the sine of a corner, and network representation of where the angle between the line and the field as well as the calculation results at each step.
\end{abstract}

Keywords: Spatial Reasoning, Gender, Problem Solving. 


\section{PENDAHULUAN}

Salah satu topik dalam geometri yang dipelajari oleh siswa di jenjang Sekolah Menengah Atas (SMA) adalah dimensi tiga. Materi dimensi tiga yang diajarkan meliputi konsep kedudukan titik, garis, dan bidang dalam ruang dimensi tiga; jarak dari titik ke garis dan jarak dari titik ke bidang dalam ruang dimensi tiga, serta besar sudut antara garis dan bidang dan antara dua bidang dalam ruang dimensi tiga. Sehingga diasumsikan bahwa dengan diajarkannya dimensi tiga siswa memahami konsep kedudukan titik, garis, bidang dalam ruang dimensi tiga, jarak dari titik ke garis dan jarak dari titik ke bidang, serta besar sudut antara garis dan bidang dan antara dua bidang untuk memecahkan permasalahan dimensi tiga (geometri). Namun berdasarkan hasil penelitian Hidayat, dkk (2013) siswa melakukan kesalahan dalam memahami konsep jarak antara dua bidang. Kurniasari (2013) terdapat kesalahan konsep yang dilakukan siswa meliputi kesalahan pada konsep jarak dan konsep sudut. Kesalahankesalahan tersebut akibat kurangnya pemahaman terhadap konsep. Siswa hanya terbiasa memahami konsep terbatas pada materi dan contoh soal.

Penting bagi siswa memahami suatu konsep, karena dengan memahami suatu konsep siswa dapat mengaitkan antara konsep yang satu dengan yang lain dan menggunakannya dalam pemecahan masalah. Berdasarkan tujuan diajarkannya matematika baik pada Kurikulum 2006 maupun pada Kurikulum 2013, tujuan pertama setelah siswa belajar matematika adalah diharapkan siswa memiliki pemahaman matematika. Hiebert dan Carpenter (1992) mengungkapkan bahwa matematika dipahami secara menyeluruh jika representasi mental adalah bagian dari jaringan representasi. Selanjutnya Barmby dkk (2007) mendefinisikan pemahaman adalah jaringan representasi yang terkait dengan konsep matematika.

Pemahaman merupakan landasan keterampilan pemecahan masalah, karena keterampilan pemecahan masalah tidak lepas dari tindakan yang didasari oleh berpikir secara mendalam. Untuk memecahkan masalah diperlukan suatu pendekatan tertentu, dan dalam penelitian ini pendekatan yang digunakan seperti yang diunggapkan Polya. Polya (1973) mengajukan empat langkah/fase pemecahan masalah, yaitu: (1) memahami masalah (understanding the problem); (2) menyusun rencana (devising a plan); (3) melaksanakan rencana (carrying out the plan); dan (4) memeriksa kembali (looking back).

Kemampuan setiap individu untuk menerima dan mengolah suatu informasi bahkan dalam memecahkan masalah pasti berbeda. Hal ini dipe-ngaruhi oleh berbagai hal, salah satunya adalah perbedaan kemampuan matematika. Rasiman (2013) mengungkapkan bahwa siswa berkemampuan matematika tinggi, sedang, dan rendah memperlihatkan perbedaan dalam memecahkan masalah matematika. Perbedaan ini meliputi pada fase memahami masalah, merencanakan, melaksanakan, dan memeriksa kembali.

Berdasarkan uraian sebelumnya maka dalam penelitian ini bertujuan untuk mendeskripsikan pemahaman siswa berkemampuan matematika tinggi dalam 
pemecahan masalah matematika dimensi tiga.

Hiebert dan Carpenter (1992: 67) mengungkapkan

"The mathematics is understood if its mental representation is part network of representations. The degree of understanding is determined by the number and strength of its connections. A mathematical idea, procedure, or fact is understood thoroughly if it is linked to existing networks with stronger or more numerous connections"

Lebih khusus lagi Hiebert dan Carpenter (1992) mengungkapkan bahwa matematika dipahami secara menyeluruh jika representasi mental adalah bagian dari jaringan representasi. Selanjutnya Barmby dkk (2007) mendefinisikan pemahaman adalah jaringan representasi yang terkait dengan konsep matematika. Representasi adalah model atau pengganti atau bentuk pengganti dari suatu situasi masalah atau aspek dari situasi masalah yang digunakan untuk menemukan solusi (Jones dan Knuth, 2005). Berdasarkan beberapa pendapat tersebut maka pemahaman yang dimaksud dalam peneltitian ini adalah keterkaitan antara informasi tentang suatu objek dengan jaringan representasi yang telah dimiliki.

Hiebert dan Carpenter (dalam Barmby, dkk, 2007) mengungkapkan meskipun pemahaman dalam matematika didasarkan pada representasi internal dalam pengajaran dan penilaian, yang sebenarnya kita gunakan untuk mengetahui pemahaman siswa adalah representasi “eksternal”. Sebagai contoh, representasi eksternal seperti bahasa lisan, simbol tertulis, gambar dan benda-benda fisik yang digunakan untuk berkomunikasi matematika.

Krulik dan Rudnick (dalam Carson, 2007) masalah adalah suatu situasi yang dihadapi oleh seseorang atau kelompok yang memerlukan suatu pemecahan tetapi individu atau kelompok tersebut tidak memiliki cara yang langsung untuk menemukan solusinya. Dan Shadiq (2004) mengungkapkan bahwa masalah merupakan situasi yang harus direspon, tetapi tidak semua situasi dapat dikatakan masalah, situasi akan menjadi masalah jika situasi itu menunjukkan suatu tantangan (challange) yang tidak dapat diselesaikan dengan prosedur rutin (routine procedure).

Masalah matematika dalam penelitian ini adalah suatu soal matematika yang solusinya tidak dapat ditemukan segera yang hanya dengan menggunakan pengetahuan yang telah diperoleh sebelumnya tetapi memerlukan pemikiran lanjut untuk mengkaitkan pengetahuan sebelumnya sehingga dapat menemukan solusi untuk pertanyaan tersebut. Pada penelitian ini masalah dimensi tiga (geometri) yang akan digunakan mengacu pada kedua kompetensi dasar, yaitu (1) menentukan jarak antara titik dan bidang dalam ruang dimensi tiga; (2) menentukan besar sudut antara garis dan bidang dalam ruang dimensi tiga.

Polya (1973) menyatakan "Solving a problem is finding the unknown means to a distinctly conceived end". Pemecahan masalah adalah suatu usaha untuk menemukan sesuatu yang belum diketahui dengan cara yang sesuai. Pemecahan 
masalah matematika yang dimaksud dalam penelitian ini adalah usaha untuk memperoleh suatu solusi dari permasalahan matematika, dengan menggunakan empat fase/langkah yang dikemukakan oleh Polya (1973) yaitu memahami masalah, menyusun rencana, melaksanakan rencana, memeriksa kembali.

Pemahaman dalam pemecahan masalah merupakan keterkaitan antara informasi tentang suatu objek dengan jaringan representasi yang telah dimiliki oleh seseorang dengan langkah-langkah pemecahan masalah. Langkah pemecahan masalah yang dimaksud adalah langkah pemecahan masalah berdasarkan langkah Polya.

Adapun indikator yang dikembangkan berdasarkan adaptasi dari Polya (1973), dan Hiebert dan Carpenter (1992) untuk melihat pemahaman dalam pemecahan masalah matematika sebagai berikut.

a. Pemahaman Memahami Masalah

1. Keterkaitan antara informasi yang diketahui dan yang ditanyakan pada masalah dengan jaringan representasi.

b. Pemahaman Memahami Masalah

1. Keterkaitan antara informasi pada masalah dengan jaringan representasi tentang tugas lain yang serupa.

2. Keterkaitan antara informasi pada masalah dengan jaringan representasi tentang pengetahuan atau konsep apa yang akan digunakan untuk memecahkan masalah.
3. Keterkaitan antara informasi pada masalah dengan jaringan representasi tentang langkahlangkah yang akan dilakukan.

c. Pemahaman Melaksanakan

1. Keterkaitan antara informasi pada masalah dengan jaringan representasi tentang gambar kubus.

2. Keterkaitan antara informasi yang diperoleh pada setiap langkah yang dilakukan dengan jaringan representasi.

d. Pemahaman Memeriksa Kembali

1. Keterkaitan antara informasi hasil akhir yang diperoleh dengan jaringan representasi.

2. Keterkaitan antara informasi hasil yang diperoleh pada langkahlangkah yang dilakukan dengan jaringan representasi.

\section{METODE PENELITIAN}

Penelitian ini merupakan jenis penelitian eksploratif dengan pendekatan kualitatif. Subjek dalam penelitian ini siswa kelas X-10 SMA Negeri 15 Surabaya yang memiliki kemampuan matematika tinggi. Instrumen dalam penelitian ini, dibedakan menjadi dua, yaitu (1) instrumen utama, dan (2) instrumen pendukung. Insrumen utama adalah peneliti sendiri.

Instrumen pendukung dalam penelitian ini terdiri dari 3 macam, yaitu tes kemampuan matematika, tugas pemecahan masalah (TPM), dan pedoman wawancara. Pengumpulan data menggunakan metode wawancara yang dilakukan oleh peneliti sebagai instrumen utama. Wawancara dalam penelitian ini menggunakan wawancara semi terstruktur. Wawancara dilakukan 
untuk menggali pemahaman subjek dalam pemecahan masalah dimensi tiga. Pada penelitian ini, dilakukan pengumpulan data sebanyak dua kali, jarak waktu antara pengumpulan data pertama dan kedua adalah dua minggu.

Untuk mengetahui keabsahan data yang diperoleh, maka perlu dilakukan uji kredibilitas data. Uji kredibilitas data merupakan pengujian derajat kepercayaan terhadap data yang diperoleh, untuk memeriksa kekredibilitasan data digunakan triangulasi waktu. Data dikatakan valid jika terdapat konsistensi atau banyak kesamaan pandangan antara data pertama dan data kedua. Kesamaan pandangan yang dimaksud adalah kesamaan makna antara hasil tertulis atau penyataan lisan atau aktivitas yang dilakukan pada TPM 1 dengan hasil tertulis atau penyataan lisan atau aktivitas yang dilakukan pada TPM 2 . Jika data belum valid maka dilakukan pengumpulan data kembali diwaktu yang berbeda dengan sebelumnya sampai diperoleh data yang valid.

Data hasil pemecahan masalah dan wawancara yang diperoleh selanjutnya dianalisis dengan pendekatan kualitatif. Analisis tes pemecahan masalah mengacu pada indikator pemahaman yang telah dipaparkan. Tahapan analisis data dalam penelitian ini adalah klasifikasi/kategorisasi data, reduksi data, penyajian data, interpretasi/penafsiran data, dan penarikan kesimpulan.

\section{HASIL PENELITIAN DAN PEMBA- HASAN}

Berdasarkan penelitian yang telah dilakukan, diperoleh hasil penelitian pemahaman subjek (KT) dalam pemecahan masalah dimensi tiga menggunakan langkah-langkah pemecahan masalah Polya yaitu, memahami masalah, menyusun rencana, melaksanakan, dan memeriksa kembali. Berikut akan dipaparkan pemahaman subjek berdasarkan langkahlangkah pemecahan masalah.

\section{Pemahaman Subjek dalam Fase Mema- hami Masalah}

Pada fase memahami masalah, terdapat keterkaitan antara informasi pada masalah dengan jaringan repesentasi yang dimiliki subjek. Subjek memiliki jaringan representasi luas permukaan kubus, letak titik pada rusuk yang dinyatakan dalam bentuk perbandingan, titik potong diagonal sisi alas, sinus suatu sudut, sudut antara garis dan bidang.

Hiebert dan Carpenter (dalam Barmby, dkk, 2007) mengungkapkan meskipun pemahaman dalam matematika didasarkan pada representasi internal dalam pengajaran dan penilaian, yang sebenarnya kita gunakan untuk mengetahui pemahaman siswa adalah representasi "eksternal". Dalam hal ini fase memahami masalah representasi eksternal subjek yang muncul dalam bentuk bahasa lisan dan tulisan pada lembar jawaban. Pada petikan wawancara di atas terlihat bahwa subjek mengungkapkan kembali masalah yang diberikan dengan bahasa sendiri. Simon (dalam Susanto, 2011), menyatakan bahwa seseorang dikatakan dapat memecahkan masalah dengan sempurna jika dia memahami masalah tersebut terlebih dahulu sehingga mampu mengungkapkan masalah tersebut dengan kata-kata sendiri dan jika diberikan masalah yang serupa dengan konteks yang berbeda, dia juga akan bisa memecahkan masalah tersebut. 


\section{Pemahaman Subjek dalam Fase Menyu- sun Rencana}

Pada fase menyusun rencana, terdapat keterkaitan antara pertanyaan menentukan nilai sinus suatu sudut dengan jaringan representasi yang dimiliki subjek yaitu soal menentukan sinus suatu sudut dan pengetahuan yang digunakan.

Pada petikan wawancara

"Mencari panjang rusuknya dulu, dari yang diketahui luas permukaan nanti akan menemukan panjang rusuk kubusnya. Terus perbandingan, dan menentukan diagonal sisi ini." dan

"Menggunakan rumus sin cos tan juga."

dalam petikan wawancara ini, terlihat bahwa terdapat keterkaitan antara informasi pada masalah dengan jaringan representasi tentang pengetahuan-pengetahuan yang akan digunakan untuk memecahkan masalah, yaitu rumus luas permukaan kubus, perbandingan, diagonal sisi, dan rumus sinus, cosinus, dan tangen. Dan juga pada petikan wawancara

"Langkahnya, ditulis dulu diketahuinya, digambar kubusnya, terus dicari panjang rusuknya dari luas permukaan, rumusnya $6 s^{2}$. Terus dituliskan pada gambarnya, terus mencari titik $P$ di $C G$ yang ditentukan dari perbandingannya, terus cari sudut $\theta$ itu ada di mana kemudian mencari nilai dari $\sin \theta$.",

terlihat bahwa terdapat keterkaitan informasi pada masalah dengan jaringan representasi yang dimiliki subjek yaitu langkah-langkah yang akan dilakukan. Langkah-langkah yang disusun oleh subjek untuk memecahkan masalah yaitu menulis diketahui dan ditanya, meng- gambar kubus, menentukan panjang rusuk dengan menggunakan luas permukaan kubus yang diketahui, menentukan letak titik pada rusuk menggunakan perbandingan, menentukan titik potong diagonal sisi alas, menentukan letak sudut antara garis dan bidang dan selanjutnya menentukan nilai dari sinus sudut.

Berdasarkan petikkan wawancara subjek mengungkapkan pernah mengerjakan masalah yang serupa dengan masalah yang diberikan dan mengungkapkan pengetahuan yang digunakan dalam memecahkan masalah yang serupa tersebut. Dan juga subjek mengungkapkan pengetahuan-pengetahuan yang akan digunakan beserta langkah-langkah yang akan dilakukan dalam memecahkan masalah yang diberikan. Hal ini menyatakan bahwa terdapat hubungan antara informasi pada masalah dengan jaringan reprsentasi yang dimiliki subjek dan kuatnya hubungan tersebut. Sejalan yang diungkapkan Hiebert dan Carpenter (1992: 67) "A mathematical idea, procedure, or fact is understood thoroughly if it is linked to existing networks with stronger or more numerous connections".

\section{Pemahaman Subjek dalam Fase Melak-} sanakan

Pada fase melaksanakan, terdapat keterkaitan antara informasi kubus pada masalah dengan jaringan representasi yang dimiliki subjek tentang bangun kubus. Pada tahap melaksanakan, setelah menuliskan apa yang diketahui dan apa yang ditanyakan subjek menggambar kubus. Hal ini menyatakan bahwa subjek memiliki jaringan representasi tentang kubus beserta unsur diagonal sisi alas dan menggambar suatu bidang. berikut adalah petikan 
wawancara subjek memecahkan masalah pada fase melaksanakan.

Terdapat keterkaitan antara informasi pada setiap langkah yang dilakukan dengan jaringan representasi yang dimiliki subjek. Adapun representasi yang dimiliki subjek yaitu luas permukaan kubus. Subjek menggunakan luas permukaan kubus untuk menentukan panjang rusuk kubus, dapat dilihat pada petikan wawancara

"Mencari panjang rusuknya, dari

luas permukaan yang diketahui.".

Terdapat keterkaitan antara letak titik pada rusuk yang dinyatakan dalam bentuk perbandingan dengan jaringan reprenstasi yang dimiliki subjek. Ini terlihat dari subjek menentukan letak titik pada rusuk dengan menggunakan perbandingan yang diketahui

Terdapat keterkaitan informasi letak sudut antara garis dan bidang dengan jaringan representasi yang dimiliki subjek. Hal ini terlihat pada subjek meletakkan sudut yang ditanyakan berada diantara garis diketahui dengan garis perwakilan dari bidang, dan jika garis-garis tersebut dihubungkan maka akan membentuk segitiga siku-siku . Ini menunjukkan bahwa KT salah dalam mengabstraksi sudut antara garis dan bidang. Seperti yang diungkapkan Kurniasari (2013) bahwa salah satu kesalahan siswa dalam menyelesaikan soal dimensi tiga adalah kesalahan abstraksi sudut antara garis dan bidang.

Terdapat keterkaitan antara sinus suatu sudut dengan jaringan representasi yang dimiliki subjek. Ini terlihat dari subjek menentukan nilai sinus suatu sudut dengan menggunakan rumus perbandingan panjang sisi miring dan panjang sisi depan Terdapat keterkaitan antara panjang diagonal sisi kubus dengan jaringan representasi yang dimiliki subjek. Hal ini terlihat pada subjek menentukan panjang diagonal sisi kubus menggunakan rumus Phytagoras. Terdapat keterkaitan antara pecahan yang penyebutnya dalam bentuk akar dengan jaringan representasi yang dimiliki subjek. Ini terlihat pada subjek merasionalkan penyebut dari pecahan tersebut dengan mengalikan dengan sekawan dari penyebut.

Sama halnya dengan pemahaman subjek pada fase menyusun rencana, ini menyatakan bahwa terdapat keterkaitan antara informasi pada masalah dengan jaringan reprsentasi yang telah dimiliki subjek. Dalam hal ini informasi-informasi yang diperoleh pada setiap langkah yang dilakukan berhubungan dengan representasi subjek dan kuatnya hubungan tersebut. Seperti yang diungkapkan Hiebert dan Carpenter (1992: 67) "A mathematical idea, procedure, or fact is understood thoroughly if it is linked to existing networks with stronger or more numerous connections".

Pemahaman Subjek dalam Fase Memeriksa Kembali

Pada fase memeriksa kembali, subjek memeriksa letak sudut antara garis dan bidang, nilai dari sinus suatu sudut, dan memeriksa hasil operasi/perhitungan yang diperoleh.

Berdasarkan hasil wawancara, terlihat bahwa terdapat keterkaitan antara letak sudut yang diperoleh dengan jaringan representasi yang dimiliki subjek. Hal ini terlihat dari subjek tidak yakin dan memeriksa letak sudut yang diperoleh seperti yang diungkapkan pada transkrip wawancara

"Memastikan letak sudut $\theta$ nya, dan memperhatikan mungkin letak hurufnya beda makanya saya 
gambar lagi, tapi ternyata sama aja. Sudut pertemuan antara garis $O P$ dengan bidang BGD. Dan menentukan sudut $\theta$ nya kayaknya salah. Sudut $\theta$ nya sebenarnya tidak disini."

Dan

"Kayaknya di sini (menunjuk), OP sama OG tapi tidak berbentuk segitiga siku-siku.".

Terdapat keterkaitan antara hasil akhir yang diperoleh dengan jaringan representasi yang dimiliki subjek, hal ini dapat dilihat pada wawancara

"Karena tidak ada sin $\theta$ yang hasilnya itu $1 / 3 \sqrt{ } 3$."

Dan juga terdapat keterkaitan antara hasil perhitungan/pekerjaan setiap langkah dengan jaringan representasi yang dimiliki subjek. Hal ini terlihat pada

"Memeriksa semua hasil

perhitungan pada setiap langkah, mungkin salah hitung."

subjek memeriksa hasil perhitungan pada setiap langkah yang dilakukan.

Pada fase memeriksa kembali, subjek memeriksa hasil akhir pekerjaan yang diperoleh apakah sudah merupakan solusi/atau jawaban dari masalah yang diberikan. Subjek mengungkapkan tidak yakin dengan solusi yang diperoleh, karena menurut subjek tidak ada nilai sinus suatu sudut yang hasilnya adalah $\frac{1}{3} \sqrt{3}$. Senada yang diunggkapkan Baroody (1993), memeriksa kembali dengan cara menentukan apakah solusi yang diperoleh masuk akal, menjawab pertanyaan/masalah yang diberikan ataukah ada solusi lain. Selain itu subjek memeriksa letak sudut antara garis dan bidang yang subjek tentukan dan memeriksa kembali hasil perhitungan yang diperoleh.

\section{KESIMPULAN}

Pemahaman KT dalam memahami masalah, subjek memiliki jaringan representasi tentang luas permukaan kubus, letak titik pada rusuk yang dinyatakan dalam bentuk perbandingan, titik potong diagonal sisi alas, dan sinus suatu sudut.

Pemahaman KT dalam menyusun rencana, subjek memiliki jaringan representasi tentang soal menentukan sinus suatu sudut, rumus luas permukaan kubus, perbandingan, diagonal sisi, dan rumus sinus, cosinus, dan tangen. Dan juga subjek memiliki jaringan representasi tentang prosedur yang akan dilakukan untuk memecahkan masalah yaitu menulis diketahui dan ditanya, menggambar kubus, menentukan panjang rusuk dengan menggunakan luas permukaan kubus yang diketahui, menentukan letak titik pada rusuk menggunakan perbandingan, menentukan titik potong diagonal sisi alas, menentukan letak sudut antara garis dan bidang dan selanjutnya menentukan nilai dari sinus sudut. .

Pemahaman KT dalam melaksanakan, subjek memiliki jaringan representasi tentang bangun kubus, luas permukaan, letak titik pada rusuk yang dinyatakan dalam bentuk perbandingan, letak sudut antara garis dan bidang, sinus suatu sudut, diagonal sisi alas, dan merasionalkan penyebut.

Pemahaman KT dalam memeriksa kembali, subjek memiliki jaringan representasi tentang nilai sinus suatu sudut, letak sudut antara garis dan bidang, dan hasil perhitungan pada setiap langkah. 


\section{DAFTAR PUSTAKA}

Barmby, P. dkk. (2007). "How Can Asses Mathematical Understanding?". In Woo, J. H., Lew, H. C., Park, K. S. \& Seo, D. Y. $(E d)$. Proceedings of the 31st Conference of the International Group for the Psychology of Mathematics Education. pp. 41-48. Seoul: PME.

Baroody, A. J. (1993). Problem Solving, Reasoning, and Communicating. New York: Macmillan Publishing Company.

Carson, J. (2007). A Problem With Problem Solving: Teaching Thinking Without Teaching Knowledge. The Mathematics Educator. 2007 Vol. 17 No 2, pp 7-14.

Hendriana, H. dan Soemarmo, U. (2014). Penilaian Pembelajaran Matematika. Bandung: PT Refika Aditama.

Hidayat, B. R., Sugiarto, B., dan Pramesti, G. (2013). "Analisis Kesalahan Siswa Dalam Menyelesaikan Soal Pada Materi Ruang Dimensi Tiga Ditinjau Dari Gaya Kognitif Siswa”. Jurnal Pendidikan Mate-matika Solusi. Surakarta: UNS Surakarta Vol.1 No.1, pp 36-46.

Hiebert, J. \& Carpenter, T. P, (1992). "Learning and Teaching with Understanding". In D Grouws, (Ed). Handbook of Research on Mathematics Teaching and Learning, 65-97. New York: MacMilan.
Jones dan Knut. (2005). Multiple Representation Skills and Creativity Effects On Mathematics Problem Solving Using A Multimedia Whiteboard System Educational Tecnology \& Society. National Central University: Taiwan.

Kurniasari, I. (2013). "Indentifikasi Kesalahan Siswa dalam Menyelesaiakan Soal Geometri Materi Dimensi Tiga Kelas XI IPA SMA". Makalah disajikan dalam Seminar Nasional Matematika dan Pendidikan Matematika di Universitas Negeri Yogyakarta, Yogyakarta, 9 November.

Rasiman. (2013). Proses Berpikir Kritis Siswa SMA dalam Menyelesaikan Masalah Matematika Ditinjau dari Perbedaan Kemampuan Matematika (Disertasi Doktoral tidak dipublikasikan). Universitas Negeri Surabaya.

Shadiq, F. (2004). Pemecahan Masalah, Penalaran, Dan Komunikasi (Disampaikan Pada Diklat Intruktur) Pengembangan Matematika SMA Jenjang Dasar. Yog-yakarta: PPG Matematika.

Susanto, H. A. (2011). "Pemahaman Mahasiswa dalam Pemecahan Masalah Pembuktian Pada Konsep Grup Berdasarkan Gaya Kognitif'. Makalah disajikan dalam Seminar Nasional Penelitian dan Penerapan MIPA Fakultas MIPA Universitas Negeri Yogyakarta, Yogyakarta, 14 Mei 2011. 
| Jurnal PRIMATIKA, Volume 8, Nomor 2, Agustus 2019

72 Pemahaman siswa berkemampuan matematika tinggi dalam pemecahan masalah dimensi tiga Kurniawan 